\title{
Chromobacterium violaceum: Important Insights for Virulence and Biotechnological Potential by Exoproteomic Studies
}

\author{
Alessandra Ciprandi • Wanderson Marques da Silva • Agenor Valadares Santos • \\ Adriano Monteiro de Castro Pimenta - Marta Sofia Peixe Carepo • \\ Maria Paula Cruz Schneider • Vasco Azevedo • Artur Silva
}

Received: 19 October 2012 / Accepted: 4 February 2013/Published online: 28 February 2013

(c) The Author(s) 2013. This article is published with open access at Springerlink.com

\begin{abstract}
Chromobacterium violaceum is a beta-proteobacterium with high biotechnological potential, found in tropical environments. This bacterium causes opportunistic infections in both humans and animals, that can spread throughout several tissues, quickly leading to the death of the host. Genomic studies identified potential mechanisms of pathogenicity but no further studies were done to confirm the expression of these systems. In this study 36 unique protein entries were identified in databank from a two-dimensional profile of $C$. violaceum secreted proteins. Chromobacterium violaceum exoproteomic preliminary studies confirmed the production of proteins identified as
\end{abstract}

\author{
A. Ciprandi · A. Silva $(\bowtie)$ \\ Núcleo de Medicina Tropical, Universidade Federal do Pará, \\ Av. Gen. Deodoro 92, Belém 66055-240, Brazil \\ e-mail: asilva@ufpa.br \\ A. Ciprandi \\ e-mail: alecip@gmail.com \\ A. Ciprandi - A. V. Santos - M. P. C. Schneider - A. Silva \\ Laboratório de Polimorfismo de DNA, Instituto de Ciências \\ Biológicas, Universidade Federal do Pará, Rua Augusto Corrêa \\ s/n, Belém 66075-900, Brazil \\ W. M. da Silva $\cdot$ V. Azevedo \\ Departamento de Biologia Geral, Instituto de Ciências \\ Biológicas, Universidade Federal de Minas Gerais, Av. Antônio \\ Carlos 6627, Belo Horizonte 31270-910, Brazil
}

\author{
A. M. de Castro Pimenta \\ Departamento de Bioquímica e Imunologia, Instituto de Ciências \\ Biológicas, Universidade Federal de Minas Gerais, Av. Antônio \\ Carlos 6627, Belo Horizonte 31270-901, Brazil

\section{S. P. Carepo} \\ REQUIMTE/CQFB, Departamento de Química, Faculdade de \\ Ciências e Tecnologia, Universidade Nova de Lisboa, \\ 2829-516 Caparica, Portugal
}

virulence factors (such as a collagenase, flagellum proteins, metallopeptidases, and toxins), allowing us to better understand its pathogenicity mechanisms. Biotechnologically interesting proteins (such as chitinase and chitosanase) were also identified among the secreted proteins, as well as proteins involved in the transport and capture of amino acids, carbohydrates, and oxidative stress protection. Overall, the secreted proteins identified provide us important insights on pathogenicity mechanisms, biotechnological potential, and environment adaptation of $C$. violaceum.

\section{Introduction}

Chromobacterium violaceum is a gram-negative $\beta$-proteobacterium commonly found in the soil and water of tropical and sub-tropical regions. Like other free-living microbes, its metabolism is characterized by its versatility, which enables the bacterium to adapt to the diverse environmental conditions to which it is exposed [6]. This bacterium can also potentially produce several useful compounds for environmental detoxification, bioprospecting, pest control, and therapeutics. Violacein, a pigment that displays cytotoxic and antibacterial activity, is an example of such a compound [8, 18].

Chromobacterium violaceum is an opportunistic pathogen for both animals and humans, with cases reported in Southeast Asia, Oceania, and the Americas [14]. The dominant route of infection for this pathogen is through exposure of injured skin to contaminated water or soil, with effects ranging from cutaneous lesions and visceral abscesses to severe sepsis, which progresses rapidly to death [17]. The quick evolution of disease and the antibiotic treatment failure result in a mortality rate of over $60 \%$ [14]. 
The analysis of $C$. violaceum genome identified several putative virulence factors, of which none have been characterized at the molecular level. Among these candidates are type II and type III secretion systems, cytolytic toxins (hemolysins and leukotoxins), metalloproteases, and lipases [7].

Protein secretion is one of the most important means by which bacteria interact with their environment. The proteins that are released into the extracellular medium have a wide range of functions, including nutrient acquisition, stress protection, and the development of host-microbe associations via the formation of biofilms for cellular adhesion and host colonization [37, 38]. This study aims to identify in the exoproteome of $C$. violaceum proteins that provide us insights on its pathogenicity mechanisms, interactions between the bacteria and their environment, stress protection, and biotechnological potential.

\section{Materials and Methods}

\section{Bacterial Strains and Growth Conditions}

For the isolation of the extracellular proteins, C. violaceum ATCC 12472 was grown in $1 \mathrm{~L}$ of a chemically defined medium $\left[\begin{array}{llllll}1.29 & \mathrm{Na}_{2} \mathrm{HPO}_{4}, & 0.25 \% & \mathrm{KH}_{2} \mathrm{PO}_{4}, \quad 0.1 \%\end{array}\right.$ $\mathrm{NH}_{4} \mathrm{Cl}, 0.002 \% \mathrm{CaCl}_{2}, 0.02 \% \mathrm{MgSO}_{4}, 2.4 \%$ glucose, $0.05 \%$ Tween-80, $4 \%$ vitamin solution (MEM vitamin solution, Invitrogen), $1 \%$ essential amino acids solution (MEM essential amino acids, Invitrogen), and $1 \%$ nonessential amino acids solution (MEM non-essential amino acids, Invitrogen)] at $28^{\circ} \mathrm{C}$ in a rotating shaker $(140 \mathrm{rpm})$ until the mid-exponential growth phase $\left(\mathrm{OD}_{720}=0.8\right)$ [16].

\section{Extraction of Extracellular Proteins}

The culture medium was centrifuged at $4,000 \times g$ for $20 \mathrm{~min}$ at $4{ }^{\circ} \mathrm{C}$. The supernatant was collected and filtered through a $0.22-\mu \mathrm{m}$ pore-diameter membrane. The proteins were extracted using a three-phase partitioning method [33]. Ammonium sulfate was added to the clarified supernatant to a final concentration of $30 \%$, and the $\mathrm{pH}$ was adjusted to 4.0. Subsequently, $n$-butanol was added in a $1: 1$ ratio to the filtered supernatant, and the mixture was incubated for $1 \mathrm{~h}$ at room temperature. Phase separation occurred after centrifugation at $2,000 \times g$ for $10 \mathrm{~min}$. The interfacial precipitate was collected and resuspended in $20 \mathrm{mM}$ Tris- $\mathrm{HCl} \mathrm{pH} 7.4$ supplemented with a protease inhibitor cocktail (GE Healthcare). The suspension was dialyzed for $48 \mathrm{~h}$ against Milli-Q-purified water using a dialysis membrane with a $12-\mathrm{kDa}$ cut-off (Sigma). The protein concentration was determined using the Bradford method [5]. Three separate protein extractions were performed from each of three independently grown cultures of C. violaceum.

Two-Dimensional Gel Electrophoresis (2DE)

The extracellular proteins $(180 \mu \mathrm{g})$ were precipitated using methanol/chloroform and dissolved in a rehydration solution (7 M urea, $2 \mathrm{M}$ thiourea, $2 \%$ CHAPS, $1 \%$ pH 3-11 NL ampholytes, $75 \mathrm{mM}$ DTT, and $0.002 \%$ bromophenol blue). The same solution was used to rehydrate the gel strips for isoelectric focusing (IEF) $(\mathrm{pH} 3-11 \mathrm{NL}, 18 \mathrm{~cm}$, GE Healthcare). IEF was performed on an Ettan ${ }^{\text {TM }}$ IPGphor $^{\text {TM }}$ (GE Healthcare) apparatus until 80,000 Vh. SDSPAGE was performed on the DALTsix (GE Healthcare) vertical apparatus using a homogeneous $15 \%$ polyacrylamide gel. Proteins were stained with Colloidal Coomassie blue [31]. Three biological replicates of 2-DE gels were digitized with an ImageScanner ${ }^{\mathrm{TM}}$ (GE Healthcare), and the resulting images were analyzed using the ImageMas$\operatorname{ter}^{\mathrm{TM}}$ 2D Platinum v7.0 software (GE Healthcare).

\section{Tryptic Digestion and Mass Spectrometry}

All spots from 2DE were picked from the gel using an Ettan $^{\text {TM }}$ Spot Picker (GE Healthcare). The tryptic digestion was performed according to Havlis et al. [24]. The peptides were concentrated, desalted using a C18 ZipTip $^{\circledR}$ (Millipore, Bellerica, MA), and stored at $-20^{\circ} \mathrm{C}$.

Aliquots $(0.5 \mu \mathrm{L})$ of the peptide solutions were mixed with $0.5 \mu \mathrm{L}$ of a $10 \mathrm{mg} / \mathrm{mL} \alpha$-cyano-4-hydroxycinnamic acid matrix, spotted onto an AnchorChip ${ }^{\mathrm{TM}}$ 600/384 (Bruker Daltonics, Bremen, Germany) target microtiter plate (MTP), and analyzed with a MALDI-TOF/TOF AutoFlex III mass spectrometer (Bruker Daltonics). The results of the MS/MS analysis were used to search the NCBI protein database using the MASCOT ${ }^{\circledR}$ software. The search parameters were as follows: type of search, peptide mass fingerprint combined with MS/MS ion search; amino acid sequence, enzyme, trypsin; fixed modification, carbamidomethylation (Cys); variable modifications, oxidation (Met); mass values, monoisotopic; peptide charge state, 11; maximum missed cleavages, 1 ; and a peptide mass tolerance of $0.05 \% \mathrm{Da}$ (50 ppm).

\section{Bioinformatics Tools}

The prediction of $C$. violaceum protein subcellular localization was performed using the SurfG+ software [2]. SecretomeP 2.0, a software available online at http://www.cbs. dtu.dk/services/SecretomeP/, was used to evaluate secretion via the non-classical pathway. The COG database (http:// www.ncbi.nlm.nih.gov/COG/) was used to obtain a functional 
classification of the proteins. The protein sequence comparisons were performed using BLAST (http://www.ncbi. nlm.nih.gov/BLAST/).

\section{Results and Discussion}

Chromobacterium violaceum was grown in a chemically defined medium, and the extracellular proteins were obtained using a three-phase fractionation method [33].

The secreted proteins were separated using 2DE, which resulted in a profile containing 338 spots (Fig. 1). All spots were selected and subjected to mass spectrometry analysis. Of these spots, 86 were identified as 36 protein entries by MS/MS followed by databank searching (Table 1). Several spots with different $\mathrm{pI}$ and MM values corresponded to the same protein entry, which was likely due to posttranslational modifications, such as the addition of prosthetic groups and/or proteolytic processing. Similar results have been reported in the literature for other exoproteome analyses, such as in Streptococcus suis [39], Herbaspirillum seropedicae [9], Rhodococcus equi [1], and Corynebacterium pseudotuberculosis [32].

Of the identified protein entries, SurfG+ only predicted that 14 were localized extracellularly, 21 were cytoplasmic, and one was exposed on the cell surface (Table 1). To predict non-classical pathway secretion, the 21 proteins predicted by SurfG + to be cytoplasmic were submitted to the SecretomeP program. Thirteen proteins exhibited SecP scores higher than 0.5 , consistent with non-classical export pathways. In silico $C$. violaceum genome analysis with
SurfG + predicted 433 extracellular proteins, $\sim 10 \%$ of all of the $C$. violaceum ORFs.

Eight protein entries $(25 \%)$ were predicted to be cytoplasmic using all of the prediction methods. Some of those proteins may have been released into the extracellular medium due to cellular lysis, and others via some unknown mechanism to perform a different function such as moonlighting proteins [26]. The elongation factor $\mathrm{Tu}(\mathrm{EF}-\mathrm{Tu})$ CV_4188 is a moonlighting protein found in exoproteomes $[1,9,29]$; different from its function as a translation factor, this protein can be combined with the membrane and localized to the cell surface to perform a new function related to pathogenicity. In Mycoplasma pneumoniae, EF-Tu can bind to fibronectin, an adhesion glycoprotein of the extracellular matrix [12, 40]. In Pseudomonas aeruginosa, the cell surface-bound EF-Tu can serve as a receptor for host factor $\mathrm{H}$ proteins and plasminogen, which allows the bacterium to evade the immune system and invade the host [27]. The presence of the EF-Tu CV_4188 in the $C$. violaceum exoproteome suggests the involvement of this protein in cell adhesion mechanisms.

Among the identified exoproteins, many are involved in cellular motility, all of which belong to the flagellar apparatus (CV_1703, CV_1706, CV_1709, CV_1710, CV_2994, and CV_3011). The flagellum may contribute to pathogenicity as a non-flagellar protein secretion system, and this apparatus may possess additional functions such as cell adhesion [28].

In agreement with the disseminated infections caused by C. violaceum, several other virulence factors were identified including a collagenase (CV_2001), which may be
Fig. 1 Two-dimensional map of the secreted proteins of $C$. violaceum, which are stained with colloidal Coomassie blue. The spot numbers refer to Table 1

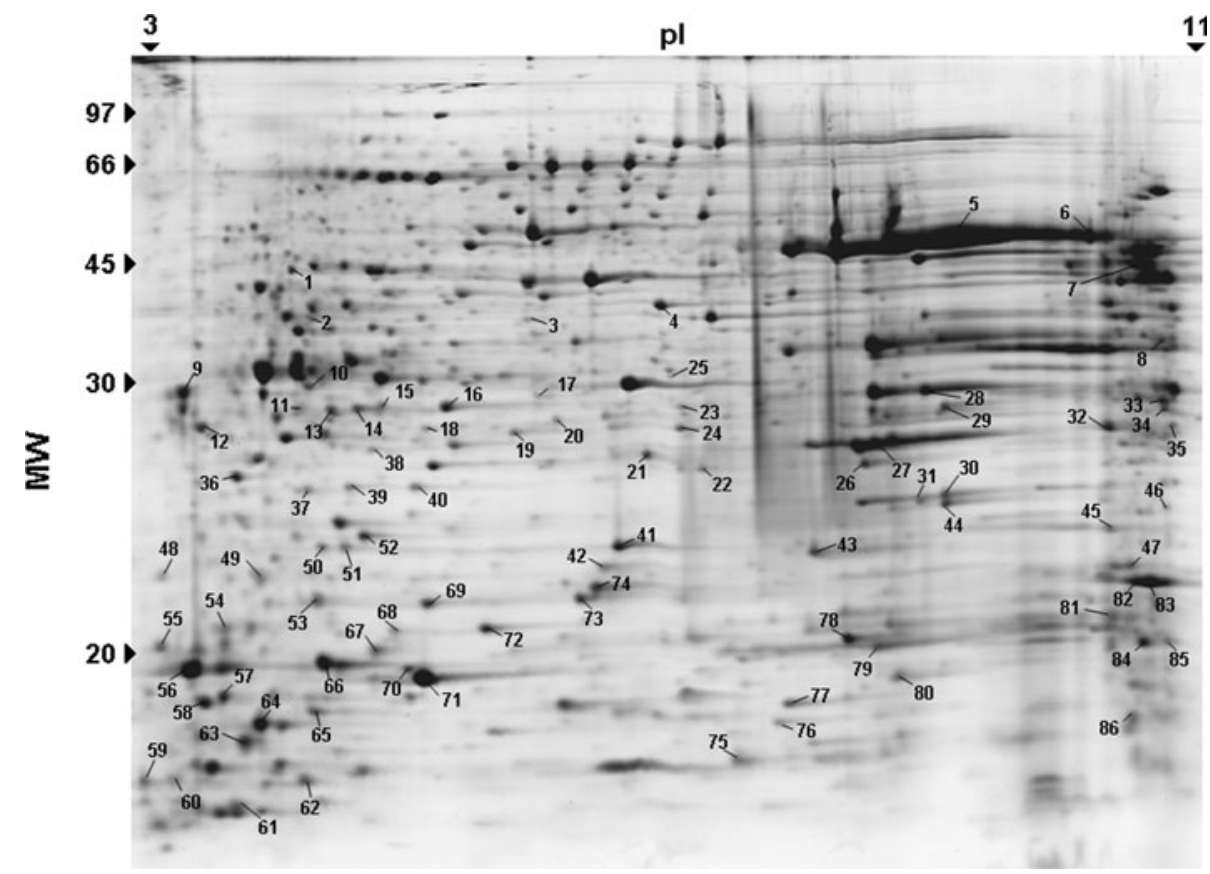


Table 1 Extracellular proteins of $C$. violaceum identified using MALDI-TOF/TOF MS

\begin{tabular}{|c|c|c|c|c|}
\hline Spot $n^{\circ}$ & $\begin{array}{l}\text { Locus } \\
\text { tag }\end{array}$ & Protein & $\begin{array}{l}\text { Cellular } \\
\text { localization }^{\mathrm{a}}\end{array}$ & $\begin{array}{l}\mathrm{COG} \\
\text { Class }^{\mathrm{b}}\end{array}$ \\
\hline $1,28,32,40,51,64,67,71$ & CV_1097 & $\begin{array}{l}\text { Binding protein component of } \mathrm{ABC} \text { dipeptide } \\
\text { transporter }\end{array}$ & $\mathrm{E}$ & $\mathrm{E}$ \\
\hline 2 & CV_1709 & Flagellar hook-associated protein FlgK & $\mathrm{C}$ & $\mathrm{N}$ \\
\hline 3 & CV_3931 & Chitosanase A & $\mathrm{E}$ & $\mathrm{G}$ \\
\hline $4,10,33,43,44,82$ & CV_2001 & Collagenase & $\mathrm{C}$ & $\mathrm{O}$ \\
\hline 5 & CV_3475 & Hypothetical protein CV_3475 & $\mathrm{E}$ & $\mathrm{S}$ \\
\hline $\begin{array}{l}6,8,18,35,45,46,52,53 \\
57,59,70,76,77,79\end{array}$ & CV_1440 & Hydrolase transmembrane protein & $\mathrm{E}$ & $\mathrm{R}$ \\
\hline 7 & CV_4329 & $\begin{array}{l}\text { Oligopeptide } \mathrm{ABC} \text { transporter system, } \\
\text { substrate-binding protein }\end{array}$ & $\mathrm{E}$ & $\mathrm{E}$ \\
\hline 9,16 & CV_3739 & Peroxidase & $\mathrm{C}$ & $\mathrm{P}$ \\
\hline 11,85 & CV_0349 & Hypothetical protein CV_0349 & $\mathrm{C}$ & $\mathrm{S}$ \\
\hline $12,42,58,60,63,68,69,86$ & CV_4107 & Hypothetical protein CV_4107 & PSE & $\mathrm{S}$ \\
\hline $13,19,21$ & CV_1710 & Flagellar hook-associated protein FlgL & $\mathrm{C}$ & $\mathrm{N}$ \\
\hline 14 & CV_4224 & Hypothetical protein CV_4224 & $\mathrm{C}$ & $\mathrm{S}$ \\
\hline $15,27,31,41$ & CV_0350 & Phage sheath protein & $\mathrm{C}$ & $\mathrm{R}$ \\
\hline $17,18,66$ & CV_3323 & Carbohydrate-binding protein & $\mathrm{E}$ & $\mathrm{S}$ \\
\hline $20,49,56$ & CV_2994 & Flagellar hook-associated protein FliD & $\mathrm{C}$ & $\mathrm{N}$ \\
\hline 22,36 & CV_1706 & Flagellar basal body rod protein FlgG & $\mathrm{C}$ & $\mathrm{N}$ \\
\hline $23,24,55,62,78$ & CV_3977 & Hypothetical protein CV_3977 & $\mathrm{C}$ & $\mathrm{S}$ \\
\hline 25 & CV_0362 & Thermolabile hemolysin, lecithin-dependent & $\mathrm{C}$ & $\mathrm{R}$ \\
\hline 26 & CV_0867 & Superoxide dismutase & $\mathrm{E}$ & $\mathrm{P}$ \\
\hline 29,30 & CV_1369 & Hypothetical protein CV_1369 & $\mathrm{E}$ & $\mathrm{S}$ \\
\hline 34 & CV_3276 & Hypothetical protein CV_3276 & $\mathrm{E}$ & $\mathrm{S}$ \\
\hline $36,54,61$ & CV_2893 & Hypothetical protein CV_2893 & $\mathrm{E}$ & $\mathrm{S}$ \\
\hline 37,83 & CV_4188 & Elongation factor $\mathrm{Tu}$ & $\mathrm{C}$ & $\mathrm{J}$ \\
\hline $38,39,47,49,73,75$ & CV_3011 & Flagellin D & $\mathrm{C}$ & $\mathrm{N}$ \\
\hline 48 & CV_0223 & Hypothetical protein CV_0223 & $\mathrm{C}$ & $\mathrm{H}$ \\
\hline 50 & CV_3506 & Protease precursor & $\mathrm{E}$ & $\mathrm{R}$ \\
\hline 54 & CV_0408 & Hypothetical protein CV_0408 & $\mathrm{C}$ & $\mathrm{S}$ \\
\hline 57 & CV_1703 & Flagellar basal body rod modification protein & $\mathrm{C}$ & $\mathrm{N}$ \\
\hline 65 & CV_4240 & Chitinase & $\mathrm{E}$ & G \\
\hline 71 & CV_2390 & Riboflavin synthase subunit beta & $\mathrm{C}$ & $\mathrm{H}$ \\
\hline 71 & CV_0340 & Tail fiber assembly protein & $\mathrm{C}$ & $\mathrm{R}$ \\
\hline 72 & CV_0424 & Hypothetical protein CV_0424 & $\mathrm{C}$ & $\mathrm{R}$ \\
\hline 74 & $\mathrm{CV}_{-} 1415$ & $\gamma$-glutamyltransferase precursor & $\mathrm{E}$ & $\mathrm{E}$ \\
\hline 80 & CV_0410 & Bacteriophage tail core protein & $\mathrm{C}$ & $\mathrm{R}$ \\
\hline 81 & CV_2034 & Peptidoglycan $N$-acetylmuramoyl hydrolase & $\mathrm{E}$ & $\mathrm{M}$ \\
\hline 84 & CV_0409 & Bacteriophage tail sheath protein & $\mathrm{C}$ & $\mathrm{R}$ \\
\hline
\end{tabular}

${ }^{a} E$ extracellular protein, $C$ cytoplasmic protein, $P S E$ potentially surface-exposed protein, according to the SurfG prediction

${ }^{b}$ Classes of clusters of orthologous groups (COG): (E) amino acid transport and metabolism; (G) carbohydrate transport and metabolism; (H) coenzyme metabolism; (J) translation, ribosomal structure, and biogenesis; (M) cell envelope biogenesis; (N) cell motility and secretion; (O) posttranslational modification, protein turnover, chaperones; $(\mathrm{P})$ inorganic ion transport and metabolism; (R) general function prediction only; (S) function unknown

involved in tissue necrosis and cytopathic effects [23], and a lecithin-dependent thermolabile hemolysin (CV_0362). Some strains of $C$. violaceum exhibit hemolytic activity, and 13 ORFs related to the hemolysins are present in the
C. violaceum ATCC 12472 genome [7]. The hemolysin identified in this study show $40 \%$ sequence identity with those of Vibrio parahaemolyticus [35] and Legionella pneumophila [20], which possess phospholipase A activity 
Fig. 2 Functional classification of $C$. violaceum extracellular proteins

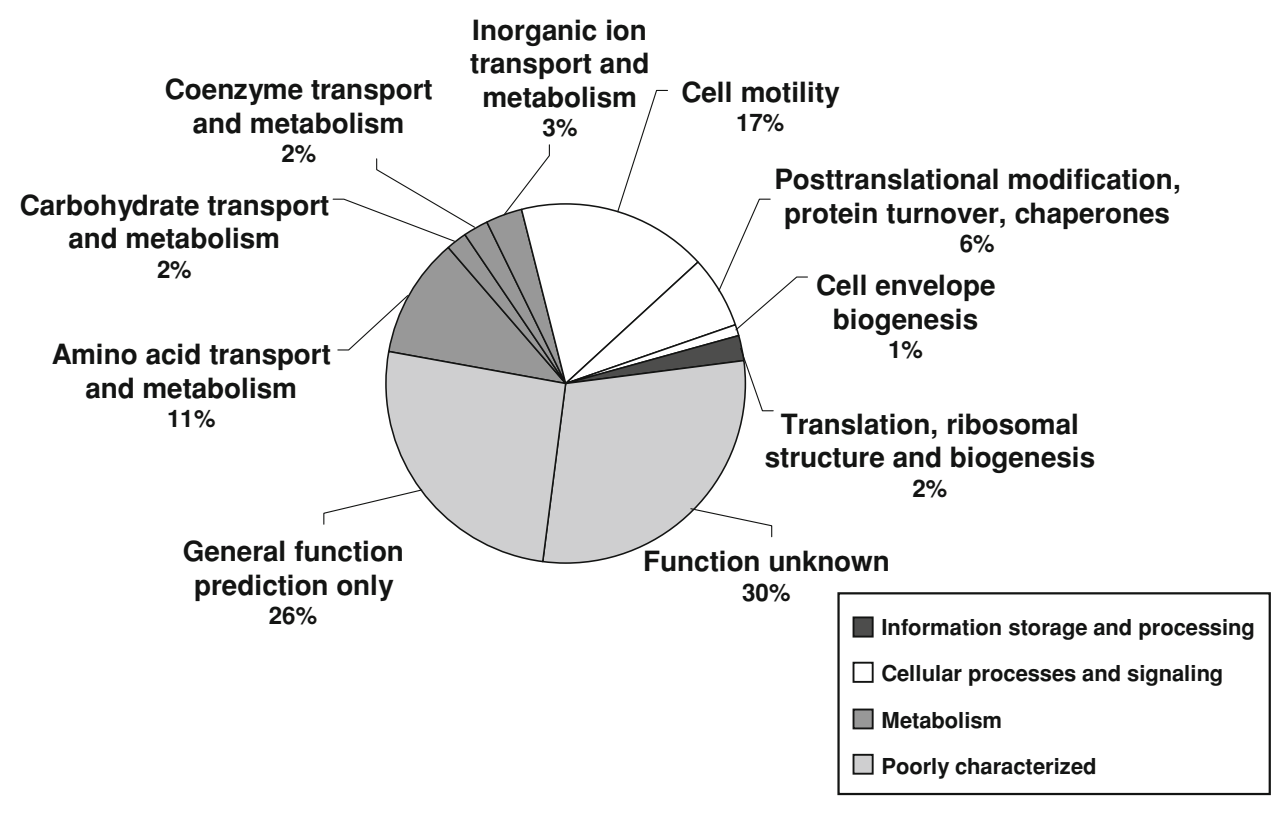

capturing oligopeptides that can serve as sources of amino acids for the cell. Oligopeptide-binding proteins can also act as intracellular signals, take part in adhesion processes, and serve as molecular chaperones [30].

Several protein entries that might be involved in carbohydrate metabolism were identified, among them are a chitosanase (CV_3931) and a chitinase (CV_4240). This finding is the first reported evidence of a chitosanase in $C$. violaceum, and our results also indicated that this enzyme is likely to be expressed constitutively, unlike most bacterial chitosanases, which are inducible. Chitosanase is responsible for the breakdown of chitosan, producing chitooligosaccharides with potential anti-tumor and anti-bacterial activities that are of great interest in both the pharmaceutical and food industries [34].

Likewise, chitinase was also expressed without chitin induction, which presents potential applications in the biological control of insects and fungi. Chernin et al. [10] detected six different types of chitinolytic activity in $C$. violaceum using a synthetic substrate, all dependent on chitin induction and the quorum-sensing system, although other chitinases may also be present [10].

Three other identified protein entries exhibited a chitinbinding motif (carbohydrate-binding protein CV_3323, transmembrane hydrolase CV_1440, and hypothetical protein CV_1369), although their functions are still unknown. These gene products may be involved in carbohydrate metabolism or in an unrelated, unknown function; the L. pneumophila chitinase, for example, enables the survival of this pathogen in the lung [15].

As a bacterium that lives exposed to the environment, $C$. violaceum requires efficient stress protection systems. Two exoproteins that might be involved in oxidative stress protection were identified: superoxide dismutase (SOD) 
and peroxidase. SOD converts $\mathrm{O}_{2}{ }^{-}$, produced by the ultraviolet irradiation of water, to $\mathrm{O}_{2}$ and $\mathrm{H}_{2} \mathrm{O}_{2}$. The presence of SOD CV_0867 in the extracellular medium is necessary because $\mathrm{O}_{2}{ }^{-}$cannot penetrate through membranes; thus, $C$. violaceum requires a system that is capable of detoxifying this molecule at its source [21]. Although $\mathrm{H}_{2} \mathrm{O}_{2}$ is able to penetrate through membranes, the presence of the peroxidase CV_3739, a member of the peroxiredoxin family, in the extracellular medium may be important for its detoxification.

Among the cytoplasmic proteins found in the extracellular milieu identified, some are related to bacteriophages (CV_0340, CV_0350, CV_0409, CV_0410, and CV_0424), which can reach the extracellular medium via holins [36]. The $C$. violaceum genome contains four prophages from different sources, designated CvP1, CvP2, CvP3, and CvP4 [13]. Proteins CV_0409, CV_0410, and CV_0424 belong to CvP2, which can display bactericidal activity [13].

Several gene products of unknown function were found in the C. violaceum exoproteome: CV_0223, CV_0349, CV_0408, CV_1369, CV_2893, CV_3276, CV_3475, and CV_4224. These proteins may have important roles in the adaptation of the bacterium to the diverse environments in which it can survive and the pathology it induces. Further biochemical structural characterization of these proteins is necessary for the determination of their extracellular function.

\section{Conclusions}

The $C$. violaceum proteins identified so far on the exoproteome comprise a wide array of molecular tools, some of which with potential biotechnological applications that are fundamental to its environmental adaptation as well as an arsenal of proteins that aid in the process of host invasion and injury. These results also confirm previously described genomic data and validate the expression and localization of the gene products identified here.

Acknowledgments This study was supported by the Brazilian Federal Agency for the Support and Evaluation of Graduate Education (Coordenação de Aperfeiçoamento de Pessoal de Nível Superior-CAPES), the National Council for Scientific and Technological Development (Conselho Nacional de Desenvolvimento Científico e Tecnológico- $\mathrm{CNPq}$ ), the Foundation of Research Support of the State of Pará (Fundação de Amparo à Pesquisa do Estado do ParáFAPESPA), and the Northern Brazil Electrical Centrals (Centrais Elétricas do Norte do Brasil-Eletronorte). MSPC would like to thank Programa Ciência 2007 and PEst-C/EQB/LA0006/2011 of Fundação para a Ciência e Tecnologia. AMPC would like to thank MCT-FINEP and FAPEMIG.
Open Access This article is distributed under the terms of the Creative Commons Attribution License which permits any use, distribution, and reproduction in any medium, provided the original author(s) and the source are credited.

\section{References}

1. Barbey C, Budin-Verneuil A, Cauchard S, Hartke A, Laugier C, Pichereau V, Petry S (2009) Proteomic analysis and immunogenicity of secreted proteins from Rhodococcus equi ATCC 33701. Vet Microbiol 135:334-345

2. Barinov A, Loux V, Hammani A, Nicolas P et al (2009) Prediction of surface exposed proteins in Streptococcus pyogenes, with a potential application to other gram-positive bacteria. Proteomics 9:61-73

3. Betts HJ, Chaudhuri RR, Pallen MJ (2004) An analysis of type-III secretion gene clusters in Chromobacterium violaceum. Trends Microbiol 12:476-482

4. Boanca G, Sand A, Barycki JJ (2006) Uncoupling the enzymatic and autoprocessing activities of Helicobacter pylori gammaglutamyltranspeptidase. J Biol Chem 281:19029-19037

5. Bradford MM (1976) A rapid and sensitive method for the quantitation of microgram quantities of protein utilizing the principle of protein-dye binding. Anal Biochem 72:248-254

6. Brazilian National Genome Project Consortium (2003) The complete genome sequence of Chromobacterium violaceum reveals remarkable and exploitable bacterial adaptability. Proc Natl Acad Sci USA 100:11660-11665

7. Brito CF, Carvalho CB, Santos F, Gazzinelli RT, Oliveira SC, Azevedo V, Teixeira SM (2004) Chromobacterium violaceum genome: molecular mechanisms associated with pathogenicity. Genet Mol Res 3:148-161

8. Carepo MS, Azevedo JS, Porto JI, Bentes-Sousa AR, Batista JDAS, Silva AL, Schneider MP (2004) Identification of Chromobacterium violaceum genes with potential biotechnological application in environmental detoxification. Genet Mol Res 3:181-194

9. Chaves DF, de Souza EM, Monteiro RA, de Oliveira Pedrosa F (2009) A two-dimensional electrophoretic profile of the proteins secreted by Herbaspirillum seropedicae strain Z78. J Proteomics 73:50-56

10. Chernin LS, Winson MK, Thompson JM et al (1998) Chitinolytic activity in Chromobacterium violaceum: substrate analysis and regulation by quorum sensing. J Bacteriol 180:4435-4441

11. Crossley RA, Gaskin DJ, Holmes K et al (2007) Riboflavin biosynthesis is associated with assimilatory ferric reduction and iron acquisition by Campylobacter jejuni. Appl Environ Microbiol 73:7819-7825

12. Dallo SF, Kannan TR, Blaylock MW, Baseman JB (2002) Elongation factor $\mathrm{Tu}$ and $\mathrm{E} 1$ beta subunit of pyruvate dehydrogenase complex act as fibronectin binding proteins in Mycoplasma pneumoniae. Mol Microbiol 46:1041-1051

13. De Almeida R, Trevilato PB, Bartoleti LA, Proença-Módena JL, Hanna ES, Gregoracci GB, Brocchi M (2004) Bacteriophages and insertion sequences of Chromobacterium violaceum. ATCC 12472. Genet Mol Res 3:76-84

14. De Siqueira IC, Dias J, Ruf H et al (2005) Chromobacterium violaceum in siblings. Brazil Emerg Infect Dis 11:1443-1445

15. Debroy S, Dao J, Söderberg M, Rossier O, Cianciotto NP (2006) Legionella pneumophila type II secretome reveals unique exoproteins and a chitinase that promotes bacterial persistence in the lung. Proc Natl Acad Sci USA 103:19146-19151 
16. Demoss RD, Happel ME (1959) Nutritional requirements of Chromobacterium violaceum. J Bacteriol 77:137-141

17. Díaz Pérez JA, García J, Rodriguez Villamizar LA (2007) Sepsis by Chromobacterium violaceum: first case report from Colombia. Braz J Infect Dis 11:441-442

18. Durán N, Menck CF (2001) Chromobacterium violaceum: a review of pharmacological and industiral perspectives. Crit Rev Microbiol 27:201-222

19. Fischer M, Bacher A (2008) Biosynthesis of vitamin B2: structure and mechanism of riboflavin synthase. Arch Biochem Biophys 474:252-265

20. Flieger A, Rydzewski K, Banerji S, Broich M, Heuner K (2004) Cloning and characterization of the gene encoding the major cellassociated phospholipase A of Legionella pneumophila, plaB, exhibiting hemolytic activity. Infect Immun 72:2648-2658

21. Fridovich I (1995) Superoxide radical and superoxide dismutases. Annu Rev Biochem 64:97-112

22. Galka F, Wai SN, Kusch H et al (2008) Proteomic characterization of the whole secretome of Legionella pneumophila and functional analysis of outer membrane vesicles. Infect Immun 76:1825-1836

23. Han HJ, Taki T, Kondo H, Hirono I, Aoki T (2008) Pathogenic potential of a collagenase gene from Aeromonas veronii. Can $\mathbf{J}$ Microbiol 54:1-10

24. Havlis J, Thomas H, Sebela M, Shevchenko A (2003) Fastresponse proteomics by accelerated in-gel digestion of proteins. Anal Chem 75:1300-1306

25. Holland C, Mak TM, Zimny-Arndt U, Schmid M, Meyer TF, Jungblut PR, Brüggemann H (2010) Proteomic identification of secreted proteins of Propionibacterium acnes. BMC Microbiol 10:230

26. Jeffery CJ (2003) Moonlighting proteins: old proteins learning new tricks. Trends Genet 19:415-417

27. Kunert A, Losse J, Gruszin C et al (2007) Immune evasion of the human pathogen Pseudomonas aeruginosa: elongation factor Tuf is a factor $\mathrm{H}$ and plasminogen binding protein. $\mathrm{J}$ Immunol 179:2979-2988

28. Lepka D, Wilharm G (2010) Flagellin genes of Yersinia enterocolitica biotype 1A: playground of evolution towards novel flagellin functions. Microb Res 2:31-36

29. Mariappan V, Vellasamy KM, Thimma JS, Hashim OH, Vadivelu J (2010) Identification of immunogenic proteins from Burkholderia cepacia secretome using proteomic analysis. Vaccine 28:1318-1324
30. Monnet V (2003) Bacterial oligopeptide-binding proteins. Cell Mol Life Sci 60:2100-2114

31. Neuhoff V, Arold N, Taube D, Ehrhardt W (1988) Improved staining of proteins in polyacrylamide gels including isoelectric focusing gels with clear background at nanogram sensitivity using Coomassie Brilliant Blue G-250 and R-250. Electrophoresis 9:255-262

32. Pacheco LG, Slade SE, Seyffert N et al (2011) A combined approach for comparative exoproteome analysis of Corynebacterium pseudotuberculosis. BMC Microbiol 11:12

33. Paule BJ, Meyer R, Moura-Costa LF et al (2004) Three-phase partitioning as an efficient method for extraction/concentration of immunoreactive excreted-secreted proteins of Corynebacterium pseudotuberculosis. Protein Exp Purif 34:311-316

34. Shimosaka M, Fukumori Y, Zhang XY, He NJ, Kodaira R, Okazaki M (2000) Molecular cloning and characterization of a chitosanase from the chitosanolytic bacterium Burkholderia gladioli strain CHB101. Appl Microbiol Biotechnol 54:354-360

35. Shinoda S, Matsuoka H, Tsuchie T, Miyoshi S, Yamamoto S, Taniguchi H, Mizuguchi Y (1991) Purification and characterization of a lecithin-dependent haemolysin from Escherichia coli transformed by a Vibrio parahaemolyticus gene. J Gen Microbiol 137:2705-2711

36. Tjalsma H, Antelmann H, Jongbloed JD et al (2004) Proteomics of protein secretion by Bacillus subtilis: separating the "secrets" of the secretome. Microbiol Mol Biol Rev 68:207-233

37. Tseng TT, Tyler BM, Setubal JC (2009) Protein secretion systems in bacterial-host associations, and their description in the gene ontology. BMC Microbiol. doi:10.1186/1471-2180-9-S1-S2

38. Van Ulsen P, Tommassen J (2006) Protein secretion and secreted proteins in pathogenic Neisseriaceae. FEMS Microbiol Rev 30: 292-319

39. Wu Z, Zhang W, Lu C (2008) Comparative proteome analysis of secreted proteins of Streptococcus suis serotype 9 isolates from diseased and healthy pigs. Microb Pathog 45:159-166

40. Young CC, Bernlohr RW (1991) Elongation factor Tu is methylated in response to nutrient deprivation in Escherichia coli. J Bacteriol 173:3096-3100

41. Zupan J, Hackworth CA, Aguilar J, Ward D, Zambryski P (2007) VirB1 promotes T-pilus formation in the vir-Type IV secretion system of Agrobacterium tumefaciens. J Bacteriol 189:6551-6563 